\title{
Importance of extracellular organic carbon production in the total primary production by tidal-flat diatoms in comparison to phytoplankton
}

\author{
Naoshige Goto ${ }^{1, *}$, Tomohiko Kawamura ${ }^{2}$, Osamu Mitamura ${ }^{3}$, Hisayoshi Terai ${ }^{1}$ \\ 'Institute for Hydrospheric-Atmospheric Sciences, Nagoya University, Furo-cho, Chikusa-ku, Nagoya 464-8601, Japan \\ ${ }^{2}$ Tohoku National Fisheries Research Institute, Shinhama, 3-27-5, Shiogama, Miyagi 985-0001, Japan \\ ${ }^{3}$ Limnological Laboratory, School of Environmental Science, The University of Shiga Prefecture, 3165, Yasaka-machi, Hikone, Shiga 522-0057, Japan
}

ABSTRACT: Microphytobenthos, mainly benthic diatoms, produce mucilages containing extracellular polymeric substances (EPS) on the cell surface. The ratios of particulate organic carbon $\left({ }^{14} \mathrm{C}\right.$-POC) and total extracellular organic carbon (TEOC: the total of extracellular dissolved organic carbon $\left[{ }^{14} \mathrm{C}-\mathrm{EDOC}\right]$ and colloidal organic carbon $\left({ }^{14} \mathrm{C}\right.$-Colloidal-OC] extracted with EDTA) to total primary production (TPP) were measured using i ${ }^{i} \mathrm{C}$-tracer to estimate the ratio for each fraction of organic carbon photosynthetically produced by microphytobenthos and phytoplankton. TEOC for microphytobenthos ranged from 42 to $73 \%$ of TPP and was made up mostly of ${ }^{14} \mathrm{C}$-Colloidal-OC. The TEOC/TPP for phytoplankton ranged from 1.5 to $22 \%$. The ratio of ${ }^{14} \mathrm{C}$-EPS to ${ }^{14} \mathrm{C}$ Colloidal-OC for microphytobenthos was 41 to $53 \%$, and for phytoplankton was 4.4 to $24 \%$. Algal species in the transitional phase were used for experiments because microphytobenthos Nitzschia hybridaeformis most abundantly produced TEOC and EPS in the transitional phase during growth in experiments studying the effect of the growth phase. By using EDTA for the extraction of extracellular organic matter, it becomes clear that excretion of colloidal organic matter by microphytobenthos has always been underestimated. These results suggest that the large amount of TEOC containing EPS produced by microphytobenthos plays a more important role than secretion of phytoplankton as a source of organic carbon for heterotrophic organisms in the intertidal-flat ecosystem.

KEY WORDS: Microphytobenthos - Extracellular organic carbon Extracellular polymeric substances

A high proportion of microphytobenthos flora is constituted by diatoms (Bacillariophyceae) belonging to the pennates (Round et al. 1990). One of the conspicuous characteristics of diatoms is the production of an

·E-mail: nao@ihas.nagoya-u.ac.jp adhesive extracellular secretion. This mucilaginous substance is secreted from the raphe and/or mucilage pores of diatoms to the outer side of the cell, covering it in various forms such as stalks, tubes, apical pads, adhering films and fibrils (Hoagland et al. 1993). This secretion is termed an extracellular polymeric substances (EPS) and mainly consists of acidic polysaccharides that may be carboxylated and/or sulfated to varying degrees. Although protein has been detected in a few species, no lipids have been found in any diatom EPS (Percival \& McDowell 1981). EPS components play an important role in the ecological strategy of diatoms (motility, sessile adhesion, antidesiccation, antibiotic and nutrient absorption, etc.) (Hoagland et al. 1993). Moreover, EPS is a source of organic matter to bacteria, deposit feeders and grazers such as post-larval abalone in food webs (Decho \& Lopez 1993, Kawamura et al. 1998).

A large number of studies have been made on the fine structure, chemical components and functions of EPS (Hoagland et al. 1993). However, only a few studies have so far been done on the ratio of EPS to primary production (Myklestad et al. 1989, Smith \& Underwood 1998). To measure the production of EPS, mucus containing EPS must be removed from the cell surface by centrifugation after facilitating the solubilization of EPS with ethylenediaminetetraacetic acid (EDTA), since EPS is bound so tightly to the cell surface (Decho 1993). However, the production of extracellular organic carbon and/or EPS has been measured for components that were fractionated only by filtration or centrifugation without EDTA. For this reason, the production of extracellular organic carbon containing EPS may have been underestimated by the methods previously used. 
The purpose of our study is to elucidate the ratio of each organic carbon fraction (particulate organic carbon $\left[{ }^{14} \mathrm{C}-\mathrm{POC}\right]$, extracellular dissolved organic carbon $\left[{ }^{14} \mathrm{C}-\mathrm{EDOC}\right]$, colloidal organic carbon $\left[{ }^{19} \mathrm{C}\right.$-ColloidalOC) extracted by EDTA] to the carbon photoassimilated by microphytobenthos and phytoplankton using ${ }^{14} \mathrm{C}$-radiotracer. In addition, we estimated the ratio of ${ }^{14} \mathrm{C}$-EPS to ${ }^{14} \mathrm{C}$-Colloidal-OC. This paper describes a series of fractionation experiments for different species in a culture of microphytobenthos and phytoplankton as well as in an algal community in natural intertidal sediment and seawater.

Materials and methods. Fractionation of photosynthetically produced organic carbon: Samples of surface sediment and seawater which were taken at Isshiki intertidal flat in Mikawa Bay, Central Japan $\left(34^{\circ} 46^{\prime} \mathrm{N}, 137^{\circ} 02^{\prime} \mathrm{E}\right.$ ) on 13 and 28 July 1998 were used for the fractionation experiments. Moreover, benthic and planktonic algal species in culture were examined. Benthic diatom flora belonging to the pennates Nitzschia longissima, Nitzschia hybridaeformis and Amphora coffeaeformis were isolated from the sediment at the Isshiki intertidal flat. Strains of phytoplankton which were cultured in our laboratory were used (Thalassiosira weissflogii and Chaetoceros decipiens [Bacillariophyceae] Nannochloropsis oculata [Eustigmatophyta], Tetraselmis sp. [Prasinophyceae]). Strains of microphytobenthos and phytoplankton were cultured in f/2 medium (Guillard \& Ryther 1962). The cultures were grown at constant temperature $\left(20^{\circ} \mathrm{C}\right)$ on a $12 \mathrm{~h}$ alternating light-dark cycle (irradiance $80 \mu \mathrm{E}$ $\mathrm{m}^{-2} \mathrm{~s}^{-1}$ ). Cultures in the transitional phase were used for experiments on the fractionation of photosynthetically produced organic carbon by algal species.

A diagram of the analytical sequence is given in Fig. 1. Glass bottles with $20 \mathrm{ml}$ of the sample algae were incubated for $1 \mathrm{~h}$ after inoculation with the antibiotic cocktail of penicillin (benzylpenicillin potassium, Wako: final concentration of $75 \mu \mathrm{g} \mathrm{ml}^{-1}$ ) and streptomycin (streptomycin sulfate, Wako: final concentration of $125 \mu \mathrm{g} \mathrm{ml} \mathrm{m}^{-1}$ ). The sample was incubated under constant temperature $\left(20^{\circ} \mathrm{C}\right)$ and irradiance $\left(200 \mu \mathrm{E} \mathrm{m} \mathrm{m}^{-2} \mathrm{~s}^{-1}\right)$ for $8 \mathrm{~h}$ after adding ${ }^{14} \mathrm{C}-\mathrm{NaHCO}_{3}$ (1 $\mathrm{ml}, 148 \mathrm{kBq} \mathrm{ml}^{-1}, \mathrm{NEN}$ ). After the incubation, the sample was immediately analyzed without fixing. An algal pellet was separated from the supernatant by filtration through Whatman GF/F filters. The supernatant $(5 \mathrm{ml})$ was acidified with $\mathrm{H}_{3} \mathrm{PO}_{4}$ solution and bubbled with purified $\mathrm{N}_{2}$. This supernatant can be defined as the ${ }^{14} \mathrm{C}$-EDOC. Isolation of EPS from the algal cells was carried out based on the method of Decho (1993). The EPS was removed from the algal celis by centrifugation $(4000 \times g$ for 10 min, 3 times, resuspending each time in the same supernatant) after algal pellets were slowly stirred in 4 mM EDTA

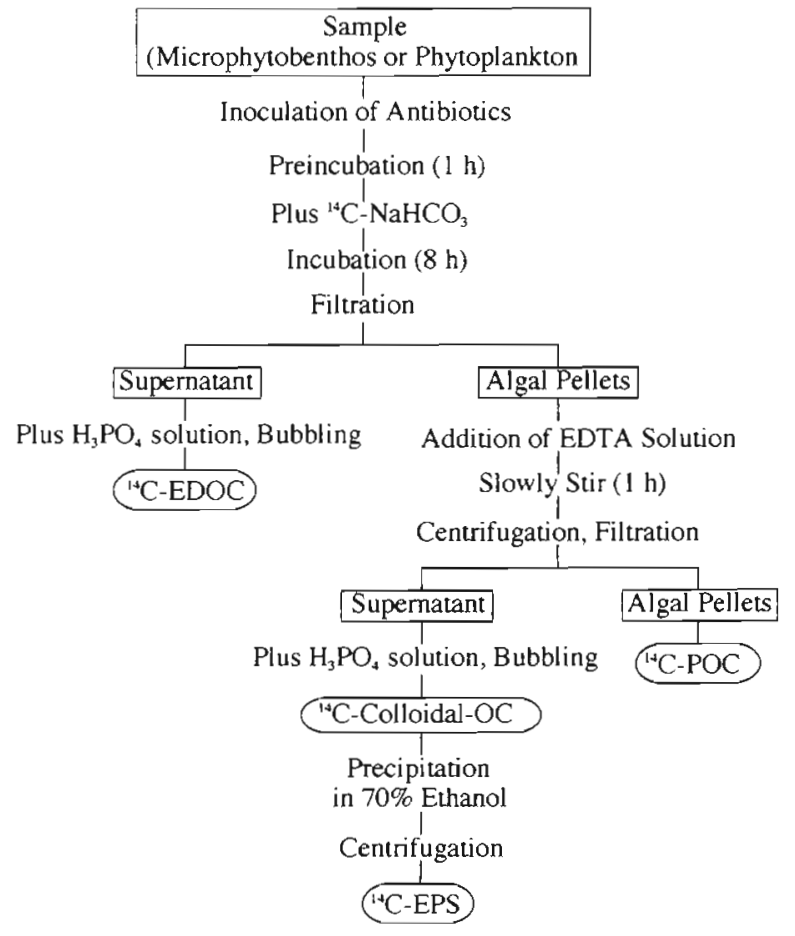

Fig. 1. Flow chart of the fractionation of photosynthetically produced organic carbon by microphytobenthos and phytoplankton. Total primary production (TPP) is defined as sum of ${ }^{14} \mathrm{C}$-POC (particulate organic carbon) and total extracellular organic carbon (TEOC: sum of ${ }^{14} \mathrm{C}$-EDOC [extracellular dissolved organic carbon] and ${ }^{14} \mathrm{C}$-Colloidal-OC [collodial organic carbon] fractions). EPS: extracellualar polymeric substance

solution for $1 \mathrm{~h}$. Algal pellets were separated from the supernatant containing soluble EPS by filtration with a Whatman GF/F filter. The filter was washed with $50 \mathrm{ml}$ of $2 \% \mathrm{HCl}$ to remove unincorporated inorganic ${ }^{14} \mathrm{C}$. This filter can be defined as the ${ }^{14} \mathrm{C}$-POC. The filtrate was acidified and bubbled as described above. This filtrate was defined as the ${ }^{14} \mathrm{C}$-Colloidal-OC. An aliquot of this filtrate was precipitated in cold $\left(4^{\circ} \mathrm{C}\right)$ ethanol (70\% final concentration) for $8 \mathrm{~h}$ and subsequently centrifuged $(4000 \times g$ for $10 \mathrm{~min}$ ), followed by a single wash with $70 \%$ ethanol and resuspension in distilled water. This extraction was repeated 2 times. Precipitation obtained by this process was defined as the ${ }^{14} \mathrm{C}$-EPS. A solution of the ${ }^{14} \mathrm{C}$-EDOC and ${ }^{14} \mathrm{C}$ Colloidal-OC fractions was poured into a scintillation vial to which $15 \mathrm{ml}$ of Aquasol-2 (Packard) was added. Adhesive precipitation of the ${ }^{14} \mathrm{C}$-EPS and the filter of the ${ }^{14} \mathrm{C}$-POC were solubilized with NSC II (Amersham) in a scintillation vial to which $10 \mathrm{ml}$ of a liquid scintillation Scintisol EX-H (Dojindo) was added. Radioactivity of each fraction was measured with a liquid scintillation spectrometer (LSC-5000, Aloka). 
In this paper, total primary production (TPP) is defined as the sum of ${ }^{14} \mathrm{C}-\mathrm{POC}$ and total extracellular organic carbon (TEOC: the total of ${ }^{14} \mathrm{C}-\mathrm{EDOC}$ and ${ }^{14} \mathrm{C}$ Colloidal-OC).

Antibiotics were used to inhibit the bacterial uptake of algal extracellular products throughout the experiment. The ratio of inhibition by antibiotics was regularly examined with $\mathrm{D}-\left[{ }^{14} \mathrm{C}(\mathrm{U})\right]$-glucose $(0.5 \mathrm{ml}, 24 \mathrm{kBq}$ $\left.\mathrm{ml}^{-1}, \mathrm{NEN}\right)$. At the same time, the influence of antibiotics on primary production was examined at the start of this study.

The algal cells (POC fraction), which were disrupted by a sonic probe, and the supernatants (Colloidal-OC fraction), which were extracted with EDTA solution, were assayed for presence of the intracellular enzyme glucose-6-phosphate dehydrogenase (G6PD, EC 1.1.1.49) activity using the method of Smyth \& Dugger (1981), to determine the extent of contamination of the extracellular polymer by intracellular material. Protein in the algal cells and the supernatant was measured by the method of Smyth \& Dugger (1981) and the Bradford method (Bradford 1976), respectively. Bovine serum albumin was used as the standard.

Experiment examining the effect of the growth phase on organic ${ }^{14} \mathrm{C}$ production in each fraction: Nitzschia hybridaeformis for the microphytobenthos and Thalassiosira weissflogii for phytoplankton were used to examine the organic ${ }^{14} \mathrm{C}$ production in each fraction during growth. Six $50 \mathrm{ml}$ glass bottles at the cell concentrations of -300 cells $\mathrm{ml}^{-1}$ for either microphytobenthos or phytoplankton were prepared at the start of the experiment. All cultures were made bacteria-free by treatment with antibiotics. Each glass bottle was cultured at a constant temperature $\left(20^{\circ} \mathrm{C}\right)$ on a $12 \mathrm{~h}$ alternating light-dark cycle (irradiance $80 \mu \mathrm{E} \mathrm{m}^{-2} \mathrm{~s}^{-1}$ ) in $\mathrm{f} / 2$ medium. Each bottle was assigned to 1 of 6 intervals corresponding to the time scale of the experiment, and each one was used for the ${ }^{14} \mathrm{C}$-uptake experiment after $0(2 \mathrm{~h}), 7,10,17,23,30 \mathrm{~d}$. They were analyzed to examine the fractionation of organic ${ }^{14} \mathrm{C}$ production in each growth phase. Fractionation of each fraction in the primary production was carried out by the abovementioned method. At the same time, the carbohydrate concentration of each fraction was measured by the phenol-sulfuric acid method using glucose as a standard (Dubois et al. 1956), after the POC fraction was hydrolyzed by the method of Myklestad \& Haug (1972).

Results. Experiment examining the effect of the growth phase on organic ${ }^{14} \mathrm{C}$ production in each fraction: The growth phase was defined based on changes in the chlorophyll a (chl a) concentration of microphytobenthos and phytoplankton as follows (Fig. 2): $7 \mathrm{~d}$ in lag phase, $10 \mathrm{~d}$ in exponential phase, $17 \mathrm{~d}$ in transitional phase, $23 \mathrm{~d}$ in stationary phase, and $30 \mathrm{~d}$ in phase of decline. Disintegrations per minute (dpm) and the ratio of the ${ }^{14} \mathrm{C}$-POC fraction to TPP of microphytobenthos were high in the exponential phase $\left({ }^{14} \mathrm{C}\right.$-POC $77.6 \%,{ }^{14} \mathrm{C}$-EDOC: $2.7 \%,{ }^{14} \mathrm{C}$-Colloidal-OC: $19.7 \%$ ) (Fig. 2). In the transitional phase, dpm and the ratio of ${ }^{14} \mathrm{C}$-Colloidal-OC to TPP increased $\left({ }^{14} \mathrm{C}\right.$-POC: $58.1 \%$, ${ }^{14} \mathrm{C}$-EDOC: $1.6 \%,{ }^{14} \mathrm{C}$-Colloidal-OC: $40.3 \%$ ). In the stationary phase, dpm and the ratio of ${ }^{14} \mathrm{C}$-EDOC to TPP increased with decreasing ${ }^{14} \mathrm{C}$-POC $\left({ }^{14} \mathrm{C}\right.$-POC: $48.7 \%,{ }^{14} \mathrm{C}$-EDOC: $11.6 \%,{ }^{14} \mathrm{C}$-Colloidal-OC: $39.7 \%$ ). Dpm and the ratio of ${ }^{14} \mathrm{C}$-EPS to ${ }^{14} \mathrm{C}$-Colloidal-OC were highest (29.5 [7 d], $31.4[10 \mathrm{~d}], 51.0$ [17 d], 27.7 [23 d], $23.1 \%$ [30 d]j in the transitional phase.

The ratio of each fraction of phytoplankton hardly changed compared with that of microphytobenthos from lag to stationary phase (the average ratio $\pm \mathrm{SD}$ of each fraction to TPP from lag to stationary phase: ${ }^{14} \mathrm{C}-\mathrm{POC}, 90.1 \pm 2.1 \% ;{ }^{14} \mathrm{C}-\mathrm{EDOC}, 3.5 \pm 1.1 \% ;{ }^{14} \mathrm{C}-$ Colloidal-OC, $6.5 \pm 1.2$ ) (Fig. 2). Dpm and the ratio of ${ }^{14} \mathrm{C}$-EPS to ${ }^{14} \mathrm{C}$-Colloidal-OC $(4.1 \pm 1.6 \%)$ were much lower than those of microphytobenthos through all growth phases

Carbohydrate concentration in POC of microphytobenthos was lower than that of EDOC and ColloidalOC throughout this experimental period (Fig. 2). On the other hand, carbohydrate concentration in POC of phytoplankton increased abruptly in the transitional phase and became higher than that of EDOC and Colloidal-OC.

Fractionation of photosynthetically produced organic carbon by algal species in culture: The ratio of ${ }^{14} \mathrm{C}$-Colloidal-OC to TPP for Nitzschia longissima and N. hybridaeformis in the microphytobenthos was almost the same as that of ${ }^{14} \mathrm{C}$-POC to TPP (Fig. 3). The ratio of ${ }^{14} \mathrm{C}$ Colloidal-OC to TPP for Amphora coffeaeformis that strongly adhered to the substrate was higher than the others $\left({ }^{14} \mathrm{C}\right.$-POC: $26.6 \%,{ }^{14} \mathrm{C}$-Colloidal-OC: $\left.70.3 \%\right)$. The ratio ${ }^{14} \mathrm{C}$-EDOC/TPP for the above 3 species was about $3 \%$. The production of TEOC by these species was equal to or greater than that of intracellular organic carbon (POC). The ratio of ${ }^{14} \mathrm{C}$-EPS $/{ }^{14} \mathrm{C}$-Colloidal-OC for $N$. longissima, $N$. hybridaeformis and $A$. coffeaeformis was $53.3,41.4$ and $43.8 \%$, respectively.

Most of the organic carbon produced by Nannochloropsis oculata and Tetraselmis sp. in the phytoplankton was ${ }^{14} \mathrm{C}$-POC $\left(N\right.$. oculata ${ }^{14} \mathrm{C}$-POC/TPP: 98.6\%; Tetraselmis sp., ${ }^{14} \mathrm{C}$-POC/TPP: $94.2 \%$ ) (Fig. 3). However, the ratio ${ }^{14} \mathrm{C}$-POC/TPP for Thalassiosira weissflogii and Chaetoceros decipiens, belonging to the centric diatoms, was a little low in comparison with the others ( $T$. weissflogir: $85.1 \%, C$. decipiens: $78.5 \%$ ). All 4 species of phytoplankton released little organic substance extracellularly compared with microphytobenthos species. The ratio ${ }^{14} \mathrm{C}$-EPS $/{ }^{14} \mathrm{C}$-Colloidal-OC of the 4 species of phytoplankton was very low, ranging from 4.4 to $9.5 \%$. 


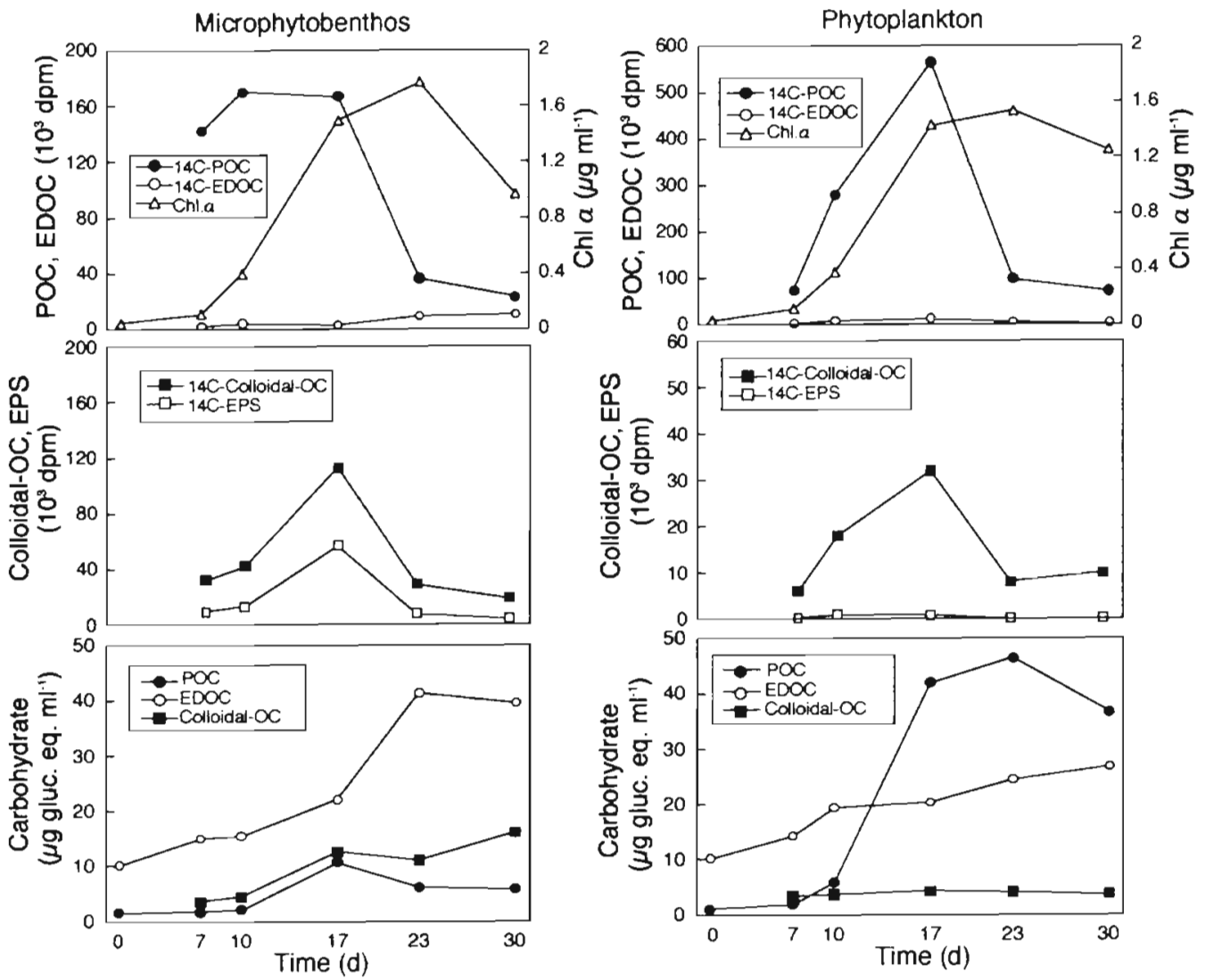

Fig. 2. Change of organic ${ }^{14} \mathrm{C}$ production in each fraction $\left({ }^{14} \mathrm{C}\right.$-POC, ${ }^{14} \mathrm{C}$-EDOC, ${ }^{14} \mathrm{C}$-Colloidal-OC and ${ }^{14} \mathrm{C}$-EPS $)$ and concentration of carbohydrate (expressed as microgram glucose equivalents ( $\mu$ g gluc. eq.) during growth of microphytobenthos Nitzschia hybridaeformis and phytoplankton Thalassiosira weissflogii

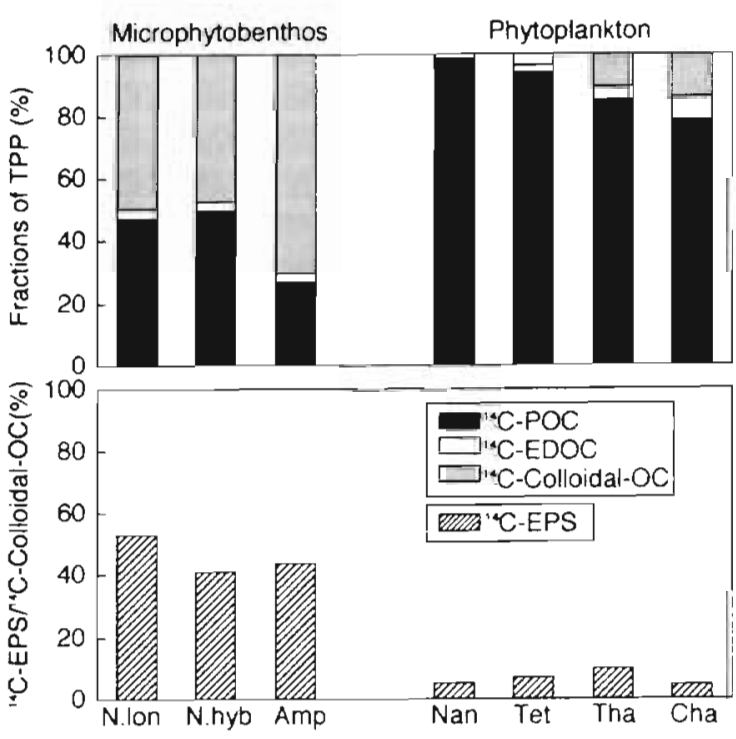

Fig. 3. Fractions of organic carbon photosynthetically produced by algal species of microphytobenthos (Nitzschia longissima [N. lon], Nitzschia hybridaeformis [N. hyb] and Amphora coffeaeformis [Amp]) and phytoplankton (Nannochloropsis oculala [Nan], Tetraselmis sp. [Tet], Thalassiosira weissflogii [Tha], Chaetoceros decipiens, [Cha])
Fractionation of photosynthetically produced organic carbon by algal community: The experiments on the fractionation of photosynthetically produced organic carbon were carried out using samples of the natural sediment (microphytobenthos community) and seawater (phytoplankton community) in the study sites. The ratios (average $\pm \mathrm{SD}$ ) of each fraction to TPP of the microphytobenthos community were as follows: ${ }^{14} \mathrm{C}-\mathrm{POC}, 57.3 \pm 3.7 \% ;{ }^{14} \mathrm{C}-\mathrm{EDOC}, 3.7 \pm 0.5 \% ;{ }^{14} \mathrm{C}-\mathrm{Col}-$ loidal-OC, $38.9 \pm 3.3 \%$ (Fig. 4). The ratio of ${ }^{14} \mathrm{C}$-EPS to ${ }^{14} \mathrm{C}$-Colloidal-OC was $41.3 \pm 1.9 \%$. The ratios (average $\pm \mathrm{SD}$ ) of each fraction to TPP of the phytoplankton community were as follows: ${ }^{14} \mathrm{C}$-POC, $81.4 \pm 1.8 \%$; ${ }^{14} \mathrm{C}-\mathrm{EDOC}, 3.5 \pm 0.5 \% ;{ }^{14} \mathrm{C}$-Colloidal-OC, $12.9 \pm 2.8 \%$ (Fig. 4). The ratio of ${ }^{14} \mathrm{C}$-EPS to ${ }^{14} \mathrm{C}$-Colloidal-OC was $24.0 \pm 3.6 \%$. Though the ratio of ${ }^{14} \mathrm{C}$-EDOC to TPP for the microphytobenthos community was almost the same as for the phytoplankton community, the ratios ${ }^{14} \mathrm{C}$-Colloidal-OC/TPP and ${ }^{14} \mathrm{C}$-EPS/ $/{ }^{14} \mathrm{C}$-Colloidal-OC of the former were much higher

The ratio of ${ }^{14} \mathrm{C}$-EPS to ${ }^{14} \mathrm{C}$-Colloidal-OC in the natural phytoplankton community $(24.0 \%)$ was higher than that of all cultured species of phytoplankton (Figs. 3 \& 4). Significant numbers of benthic diatoms 


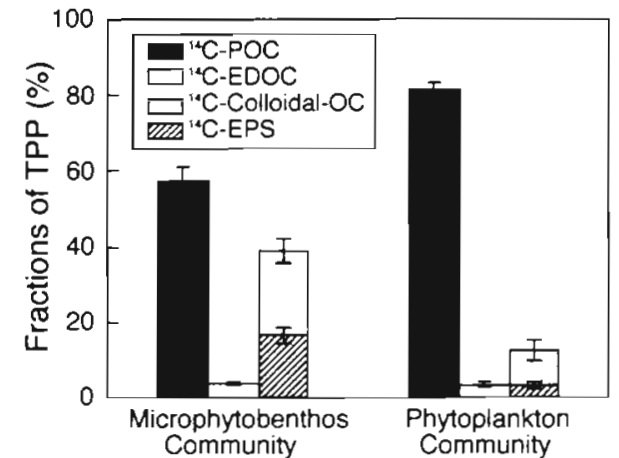

Fig. 4. Fractions of organic carbon photosynthetically produced by the microphytobenthos community in the sediment and by the phytoplankton community in the seawater (error. bars: $S D_{i} \mathrm{n}=8$ for microphyto benthos and $\mathrm{n}=3$ for phytoplankton)

are usually found in the water column of shallow-water environments (de Jonge \& Beusekom 1992). Similarly, in this investigation, Navicula spp. and Nitzschia hybridaeformis (dominant species in sediment at the present study area), usually known as benthic diatom flora belonging to the pennates, were found in the water column at the intertidal flat. Therefore, it is highly probable that they contributed to the increase in the ${ }^{14} \mathrm{C}$-EPS $/{ }^{14} \mathrm{C}$-Colloidal-OC ratio for the phytoplankton community.

Discussion. Methodology: There is the possibility that the production of DOC was underestimated because surrounding bacteria rapidly assimilate DOC released by microphytobenthos and phytoplankton (Jensen 1984). Therefore, antibiotics were used to inhibit the bacterial uptake of DOC in this study. The uptake of ${ }^{14} \mathrm{C}$-glucose by bacteria was checked to be inhibited by more than $96 \%$ with the concentration of antibiotics used. From this result, bacterial uptake was considered to be negligible. Algae were unaffected by the concentration of antibiotics, though antibiotics at high concentrations have been shown to influence the primary production of algae (Jensen 1984).

EDTA was used to facilitate the extraction of EPS from the cell surface in the present investigation. However, there is a possibility that intracellular material was extracted from the cell because EDTA ruptures the cell membranes at high concentrations (Cheng et al. 1970). Platt et al. (1985) and Decho \& Moriarty (1990) indicated that intracellular contamination in the extraction of bacterial strains was $3.3 \%$ for $10 \mathrm{mM}$ EDTA and $4.1 \%$ for $40 \mathrm{mM}$ EDTA. Underwood et al. (1995) argued that the potential for contamination of intracellular compounds was low in the extraction of intertidal sediment assemblages with $100 \mathrm{mM}$ EDTA. However, no evaluation of intracellular contamination for marine benthic and planktonic diatoms has been done. Therefore, the supernatant extracted by $4 \mathrm{mM}$ EDTA and cell pellets (microphytobenthos and phytoplankton) were assayed for both the activity of the cytoplasmic marker enzyme G6PD and the concentration of protein to determine the extent of contamination of the intracellular material in this study. Assay results using Amphora coffeaeformis and Nitzschia hybridaeformis showed that evaluation of G6PD activity and the concentration of protein in the supernatant (Colloidal-OC fraction) taken together accounted for less than $1 \%$ of the measured value for the disrupted algal cells (POC fraction), clearly establishing that few intracellular components were released from cells with 4 mM EDTA during EPS extraction.

Experiment examining the effect of the growth phase on organic ${ }^{14} \mathrm{C}$ production in each fraction: Production of intracellular and extracellular organic matter by algae varies with the growth phase. Sharp (1977) reported that the excretion of organic matter increases from the stationary to the decline phase (during the degradation of old and dying algae), although photoassimilated carbon is not excreted in large amounts in the exponential phase (during normal healthy growth). Myklestad et al. (1989) found that the marine diatom. Chaetoceros affinis excreted $58 \%$ of the products of total photosynthesis in the stationary phase, compared to $10 \%$ during exponential growth. In this study, the ratio of TEOC/TPP of microphytobenthos increased from the exponential (22.4\%) to the stationary phase $(51.3 \%)$ (Fig. 2). It has been reported that diatoms may produce considerable amounts of EPS during the latelogarithmic to the stationary phase of growth, when nutrients in the medium become limited (Myklestad et al. 1972, Decho 1993, Underwood \& Smith 1998). The production and the ratio of ${ }^{14} \mathrm{C}$-EPS to ${ }^{14} \mathrm{C}$-Colloidal$\mathrm{OC}$ of microphytobenthos were highest in the transitional phase in this study (Fig. 2). Based on our results and former studies, healthy algae in the transitional phase (when production and the ratio of extracellular organic carbon to TPP by microphytobenthos are the highest) were used for the fractionation experiment in algal species in this study.

Fractionation of photosynthetically produced organic carbon: In this study, the difference in the fractionation of photosynthetically produced organic carbon between microphytobenthos and phytoplankton was observed clearly for the algal community in sediment and seawater at the intertidal flat (Fig. 4). That is to say, the ${ }^{14} \mathrm{C}$-Colloidal-OC/TPP and ${ }^{14} \mathrm{C}$-EPS $/{ }^{14} \mathrm{C}$-Colloidal-OC ratios for the microphytobenthos community were several times higher than those for the phytoplankton community. In the present study, the result of the growth phase experiment for the carbohydrate concentration of each fraction indicated that microphytobenthos produce more TEOC containing EPS than do phytoplankton 
(Fig. 2). Smith \& Underwood (1998) measured the colloidal and EPS fractions of photoassimilated ${ }^{14} \mathrm{C}$ in an intertidal epipelic diatom assemblage using only centrifugation, without EDTA. They indicated that 8.0 to $10.9 \%$ and 0.8 to $1.0 \%$ of photoassimilated ${ }^{14} \mathrm{C}$ was incorporated into the colloidal (using only centrifugation) and EPS (precipitation in $70 \%$ ethanol) fractions, respectively. However, this may be an underestimate for the aforementioned reason. In our study, the ratios of ${ }^{14} \mathrm{C}$-Colloidal-OC and ${ }^{14} \mathrm{C}$-EPS to TPP for the microphytobenthos community were 38.9 and $16.1 \%(41.3 \%$ of ${ }^{14} \mathrm{C}$-Colloidal-OC), respectively (Fig, 4).

Chapman \& Rae (1969) found that levels of excretion (equivalent to EDOC in this study) by microphytobenthos were 1 to $3 \%$ of total carbon fixation. In the large number of studies made on levels of excretion by phytoplankton, values between 5 and $35 \%$ are usually given (Larsson \& Hagström 1979). The ${ }^{14} \mathrm{C}$-EDOC/TPP ratio for microphytobenthos and phytoplankton was almost the same in our investigation and showed a moderate value compared to that of former studies.

The ratio of each fraction to TPP for the 3 species of benthic diatoms in this study was almost the same as that for a microphytobenthos community in the sediment (Figs. 3 \& 4). However, the ${ }^{14} \mathrm{C}$-Colloidal-OC/TPP ratio for Amphora coffeaeformis reached $70 \%$. A. coffeaeformis releases adhering films consisting of EPS around the cell surface from a raphe and large puncta on the valve mantle (Daniel et al. 1980), and such films are highly adhesive (Kawamura \& Hirano 1992). This value for the ${ }^{14} \mathrm{C}$-Colloidal-OC/TPP ratio suggests that A. coffeaeformis probably adhered tightly to the substrates by excreting a large amount of mucilage, i.e. extracellular organic matter containing EPS

The percent of extracellular products to total fixed carbon varies according to class and/or species (Nalewajko 1966). In this study, 4 species of phytoplankton showed differences in the fractionation of photoassimilated carbon; the 2 species of diatoms were different to the 2 ather species. The ${ }^{14} \mathrm{C}$-POC of Nannochloropsis oculata (Eustigmatophyta) and Tetraselmis sp. (Prasinophyceae) comprised more than $95 \%$ of the TPP. However, the ${ }^{14} \mathrm{C}$-POC/TPP ratio for the 2 other diatoms, Thalassiosira weissflogii $(85.1 \%)$ and Chaetoceros decipiens $(78.5 \%)$, was lower. These results indicated that diatoms were one of the classes producing more extracellular organic carbon containing EPS.

Ecological implications: Low-molecular-weight components, amino acids and/or glucose, are contained in the Colloidal-OC fraction, except for polysaccharides (i.e. EPS) (Decho 1990), and are utilized by the bacteria (Münster \& Chróst 1990). Additionally, the mucus ]ayer (high molecular weight) of diatom surfaces is hydrolyzed by the bacterial ectoenzymes, giucosidase and/or protease and is assimilated by the bacteria (Smith et al.
1995). EPS plays a potential role as a food source for meiobenthos and macrozoobenthos (Decho 1990), i.e. it adsorbs many dissolved organic molecules (amino acids and/or fatty acids etc.) and metals (Rees 1976). Consequently, EPS significantly enhances its nutritional value to consumer animals. These reports suggest that extracellular organic matter produced by microphytobenthos might play a more important role than secretion of phytoplankton as a source of organic matter in the intertidal flat eco-system.

In addition, the adhesive EPS excreted by benthic diatoms plays an important role in stabilizing sediment of intertidal flats (Yallop et al. 1994). Therefore, the quantities of EPS is an index of the biogenic stabilization of cohesive sediments and has been used to predict the degree of biostabilization (Underwood \& Paterson 1993a,b, Yallop et al. 1994). Underwood et al. (1985) and Underwood \& Smith (1998) found that the EPS extracted by saline was only a constant fraction (ca $25 \%$ ) of the total colloidal carbohydrates pool, which has been shown to be linearly related to chl a content in the sediment. In this study, however, the production of EPS was mainly determined by the growth phase of the benthic diatom population rather than chl a concentration (Fig. 2). This result means that the stability of sediment relating to the EPS production varies depending on not only chl a content in sediments but also the physiological state of benthic diatom assemblages. Consequently, it is likely that the stability of the intertidal sediments fluctuates diurnally, seasonally and annually.

The purpose of the present study is to elucidate the production of each fraction, POC, EDOC, Colloidal-OC and EPS, by microphytobenthos in a shallow-water environment, i.e. an intertidal flat. This study demonstrated that the TEOC/TPP ratio for microphytobenthos ranged from 42 to $73 \%$ and was considerably higher than that of phytoplankton. The TEOC fraction for microphytobenthos was mostly constituted of Colloidal-OC containing EPS. The use of EDTA for the extraction of extracellular organic matter makes it clear that colloidal excretion of microphytobenthos has always been underestimated. This means that the large amount of TEOC containing EPS produced by microphytobenthos plays various important roles, as a food source for heterotrophic organisms and in sediment stability, in the intertidal-flat ecosystem.

Acknowledgements. We wish to thank Dr Koji Suzuki of the Institute for Hydrospheric-Atmospheric Sciences, Nagoya University, Japan, for providing the strain of phytoplankton, and the staff of the Isotope Center, Nagoya University. We are especially grateful to Miss Miho Nakatani tor her useful comments and encouragement throughout the study period. This study is financially supported by the Grant-in-Aid from the Aichi Fisheries Research Institute, Japan. 


\section{LITERATURE CITED}

Bradford MM (1976) A rapid and sensitive method for the quantitation of microgram quantities of protein using the principle of protein-dye binding. Anal Biochem 72 : $248-254$

Chapman G. Rae A (1969) Excretion of photosynthate by a benthic diatom. Mar Biol 3:341-351

Cheng KG, Ingram JM, Costerton JM (1970) Release of alkaline phosphatase from cells of Pseudomonas aeruginosa by manipulation of cation concentration and of $\mathrm{pH}$. J Bacteriol 104:748-753

Daniel GF, Chamberlain AHL, Jones EBG (1980) Ultrastructural observations on the marine fouling diatom Amphora. Helgol Wiss Meeresunters 34:123-149

Decho AW (1990) Microbial exopolymer secretions in ocean environments: their role(s) in food webs and marine processes. Oceanogr Mar Biol Annu Rev 28:73-153

Decho AW (1993) Methods for the observation and use in feeding experiments of microbial exopolymers. In: Kemp PF, Sherr BF, Sherr EB, Cole JJ (eds) Handbook of methods in aquatic microbial ecology. Lewis Publishers, Boca Raton, FL, p 685-694

Decho AW, Lopez GR (1993) Exopolymer microenvironments of microbial flora: multiple and interactive effects on trophic relationships. Limnol Oceanogr 38:1633-1645

Decho AW, Moriarty DJM (1990) Bacterial exopolymer utilization by a harpacticoid copepod: a methodology and results. Limnol Oceanogr 35:1039-1049

de Jonge VN, van Beusekom JEE (1992) Contribution of resuspended microphytobenthos to total phytoplankton in the Ems estuary and its possible role for grazers. Neth $J$ Sea Res 30:91-105

Dubois M, Gilles KA, Hamilton JK, Rebers PA, Smith F (1956) Colorimetric method of determination of sugars and related substances. Anal Chem 18:350-356

Guillard RRL, Ryther JH (1962) Studies of marine planktonic diatoms I: Cyclotella nana Hustedt and Detonula Confervacea (Clave) Gran. Can J Microbiol 8:229-239

Hoagland KD, Rosowski JR, Gretz MR, Roemer SC (1993) Diatom extracellular polymeric substances: function, fine structure, chemistry, and physiology. J Phycol 29:537-566

Jensen LM (1984) Antimicrobial action of antibiotics on bacterial and algal carbon metabolism: on the use of antibiotics to estimate bacterial uptake of algal extracellular products (EOC). Arch Hydrobiol 99:423-432.

Kawamura T, Hirano R (1992) Seasonal changes in benthic diatom communities colonizing glass slides in Aburatsubo Bay, Japan. Diatom Res 7:227-239

Kawamura T, Roberts RD, Takami $H$ (1998) A review of the feeding and growth of postlarval abalone. $J$ Shellfish Res $17: 615-625$

Larsson U, Hagström $\AA$ (1979) Phytoplankton exudate release as an energy source for the growth of pelagic bacteria. Mar Biol 52:199-206

Münster U, Chróst R (1990) Origin, composition, and microbial utilization of dissolved organic matter. In: Overbeck J, Chróst $R$ (eds) Aquatic microbial ecology. SpringerVerlag, New York, p 8-46

Editorial responsibility: Victor de Jonge (Contributing Editor), Harem, The Netherlands
Myklestad S, Haug A (1972) Production of carbohydrates by the marine diatom Chaetoceros affinis var. willei (Gran) Hustedt. I. Effect of the concentration of nutrients in the culture medium. J Exp Mar Biol Ecol 9:125-136

Myklestad S. Haug A, Larsen B (1972) Production of carbohydrates by the marine diatom Chaetoceros affinis var. willei (Gran) Hustedt. II. Preliminary investigation of the extracellular polysaccharide. J Exp Mar Biol Ecol 9:137-144

Myklestad S, Holm-Hansen O, Vårum KM, Volcani BE (1989) Rate of release of extracellular amino acids and carbohydrates from the marine diatom Chaetoceros affinis. J Plankton Res 11:763-773

Nalewajko C (1966) Photosynthesis and excretion in various planktonic algae. Limnol Oceanogr 11:1-10

Percival E, McDowell RH (1981) Algal walls-composition and biosynthesis. In: Tanner W, Loewus FA (eds) Plant carbohydrates II (Extracellular carbohydrate). Springer-Verlag, Berlin, p 277-316

Platt RM. Geesey GG, David JD, White DC (1985) Isolation and partial chemical analysis of firmly bound exopolysaccharide from adherent cells of a freshwater sediment bacterium. Can J Microbiol 31:675-680

Rees DA (1976) Stereochemistry and binding behavior of carbohydrate chains. In: Whelan WJ (ed) Biochemistry of carbohydrates, Vol 5. University Park Press, Baltimore, p $1-42$

Round FE, Crawford RM, Mann DG (1990) The diatoms: biology and morphology of the genera. Cambridge University Press, Cambridge

Sharp JH (1977) Excretion of organic matter by marine phytoplankton: do healthy cells do it? Limnol Oceanogr 22: 381-399

Smith DC, Steward GF, Long RA, Azam F (1995) Bacterial mediation of carbon fluxes during a diatom bloom in a mesocosm. Deep-Sea Res II 42:75-97

Smith DJ, Underwood GJC (1998) Exopolymer production by intertidal epipelic diatoms. Limnol Oceanogr 43: $1578-1591$

Smyth DA, Dugger WM (1981) Cellular changes during boron-deficient culture of the diatom Cylindrotheca fusiformis. Physiol Plant 51:111-117

Underwood GJC, Paterson DM (1993a) Recovery of intertidal benthic diatoms after biocide treatment and associated sediment dynamics. J Mar Biol Assoc UK 73:25-45

Underwood GJC, Paterson DM (1993b) Seasonal changes in diatom biomass, sediment stability and biogenic stabilization in the Severn Estuary. J Mar Biol Assoc UK 73: $871-887$

Underwood GJC, Smith DJ (1998) Predicting epipelic diatom exopolymer concentrations in intertidal sediments from sediment chlorophyll a. Microbiol Ecol 35:116-125

Underwood GJC, Paterson DM, Parkes RJ (1995) The measurement of microbial carbohydrate exopolymers from intertidal sediments. Limnol Oceanogr 40:1243-1253

Yallop ML, de Winder B, Paterson DM, Stal LJ (1994) Comparative structure, primary production and biogenic stabilization of cohesive and non-cohesive marine sediments inhabited by microphytobenthos. Estuar Coast Shelf Sci 39:565-582

Submitted: February 17, 1999; Accepted: September 21, 1999 Proofs received from author(s): November 15, 1999 